\title{
MEMAHAMI PROSES KOMUNIKASI KELOMPOK PECINTA AYAM JAGO ADUAN DI KAWASAN MANYARAN
}

\author{
Lucky Setiawan \\ (luckysetiawan729@gmail.com) \\ (Alumni Jurusan Ilmu Komunikasi Universitas Semarang)
}

\begin{abstract}
Lucky Setiawan, G.331.09.0034. Understanding the Communication Process of Rooster Fighting Lover Group in Area Manyaran. Thesis: Study Program S-1 Communication Study University of Semarang. This study aims to determine the communication process conducted in a group of Rooster Fighting Lover in western region of Semarang. In addition, it also learns the group communication process with people outside of this community. The research method used is descriptive qualitative research method by describing the characteristics of the individual and the situation of a certain group. This study is simple that does not require a complicated theoretical basis or filing certain hypotheses. It is used the technique of collecting data through interviews and observations. It is concluded that in the process of communication that exist within this group, all members adhere only to a person who is considered as a senior. In addition the communication process of the group in responding protests outside is considered extreme. The group will not pay attention to the people comments.
\end{abstract}

\section{PENDAHULUAN}

Komunikasi kelompok adalah komunikasi yang berlangsung antara beberapa orang dalam suatu kelompok "kecil" seperti dalam rapat, pertemuan, konprensi dan sebagainya (Anwar Arifin, 1984: 86). Sementara itu, Michael Burgoon (dalam Wiryanto, 2005: 98) mendefinisikan komunikasi kelompok sebagai interaksi secara tatap muka antara tiga orang atau lebih, dengan tujuan yang telah diketahui, seperti berbagi informasi, menjaga diri, pemecahan masalah, yang mana anggota-anggotanya dapat mengingat karakteristik pribadi anggotaanggota yang lain secara tepat. Kedua definisi komunikasi kelompok di atas mempunyai kesamaan, yakni adanya komunikasi tatap muka, peserta komunikasi lebih dari dua orang, dan memiliki susunan rencana kerja tertentu untuk mencapai tujuan kelompok.

Selain itu, B. Curtis, James J.Floyd, dan Jerril L. Winsor (2005: 149) juga menyatakan komunikasi kelompok terjadi ketika tiga orang atau lebih bertatap muka, biasanya di bawah pengarahan seorang pemimpin untuk mencapai tujuan atau sasaran bersama dan mempengaruhi satu sama lain. Lebih mendalam ketiga ilmuwan tersebut menjabarkan sifat-sifat komunikasi kelompok sebagai berikut:

a. Kelompok berkomunikasi melalui tatap muka;

b. Kelompok memiliki sedikit partisipan; 
c. Kelompok bekerja di bawah arahan seseorang pemimpin;

d. Kelompok membagi tujuan atau sasaran bersama;

e. Anggota kelompok memiliki pengaruh atas satu sama lain.

Kaitannya dengan penelitian ini, peneliti menggunakan konsep komunikasi kelompok tentang kelompok pecinta ayam jago aduan yang masih berlanjut hingga kini meskipun harus sembunyisembunyi agar tidak terendus pihak kepolisian. Adu ayam jago merupakan tradisi kuno yang hingga saat ini masih banyak diminati oleh banyak kalangan. Anggota kelompok pecinta ayam jago aduan yang diteliti oleh peneliti, tidak hanya kalangan orang tua namun dalam anggota tersebut juga ada pelajar yang menyukai kegiatan ini. Tradisi yang masih banyak dilakukan masyarakat ini meski dilarang agama tapi masih dilakukan. Setiap kelompok ini berkumpul pada hari minggu, dan setiap ayam jago yang dimiliki anggota kelompok selalu di adukan serta nantinya akan dievaluasi oleh kelompok.

Evaluasi tersebut biasanya mengenai proses pemberian makanan, vitamin, penjemuran ayam jago yang tepat, yang bertujuan menjadikan ayam jago Mengenai bagaimana kelompok ini menghadapi masalah yang dialaminya penulis mendapati adanya ketidakterbukaan yang tidak sejalan dengan prinsip karakteristik kelompok diantara anggota kelompok dalam menjelaskan kondisi ayam jago aduannya sebelum bertanding, dan juga pernah ditemui salah satu anggota melakukan tindakan curang dengan memberi racun kepada ayam jago lawan sebelum bertanding. Hal tersebut terkadang membuat lawan yang memiliki ayam jago aduan merasa ditipu atau dibohongi. Keterbukaan yang menjadi masalah dalam kelompok ini, digunakan sebagai dasar peneliti melakukan penelitian. Bagi anggota yang terbukti melakukan tindakan tersebut, maka anggota kelompok yang lainnya akan selalu mencurigai anggota tersebut dan anggota yang melakukan hal tersebut dipastikan akan dikeluarkan dari kelompok ini karena sudah merusak kondisi yang kohesif didalam kelompok.

\section{Perumusan Masalah.}

Setelah melihat latar belakang yang ada dan agar dalam penelitian ini tidak terjadi kerancuan, maka peneliti membatasi dan merumuskan permasalahan yang akan di angkat dalam penelitian yaitu ;

1.2.1 Bagaimana proses komunikasi kelompok para pecinta ayam jago aduan?

1.2.2 Bagaimana deskripsi masalah komunikasi kelompok dan solusinya yang ada di kelompok para pecinta ayam jago aduan?

\section{Tujuan penelitian}

Adapun tujuan peneliti melakukan penelitian ini yaitu ;

1.3.1 Mengetahui proses komunikasi kelompok para pecinta ayam jago aduan.

1.3.2 Mengetahui deskripsi masalah kelompok yang timbul dan solusinya yang ada dikelompok pecinta ayam jago aduan.

\section{TINJAUAN PUSTAKA}

\subsection{Groupthink Theory}


Penulis dalam hal ini mengkaji groupthink theory karya Irving Janis dan koleganya (Littlejohn, 2009: 346) yang menjabarkan pemikiran kelompok sebagai sebuah hasil langsung terhadap kepaduan kelompok. Kepaduan adalah tingkat minat ganda diantara anggota kelompok. Dalam sebuah kelompok yang sangat padu, sebuah identifikasi ganda menjaga sebuah kelompok bersama-sama. Kepaduan adalah sebuah hasil dari tingkatan yang semua anggota merasa bahwa tujuan mereka dapat tercapai dalam golongan. Ini tidak membutuhkan anggota yang memilki sikap yang sama, namun anggota yang menunjukan sebuah tingkatan saling ketergantugan, bersandar pada satu sama lain untuk meraih tujuan yang diinginkan. Semakin kelompok padu, tekanan akan lebih mendesak anggota untuk menjaga kepaduan tersebut.

Kepaduan dapat menjadi hal baik karena membawa anggotanya bersama dan mempererat hubungan antarpribadi. Namun dalam penelitian Janis, pemikiran kelompok dapat pula menghasilkan sesuatu yang negatif, seperti :

a. Kerlompok membatasi diskusi hanya untuk beberapa alternatif tanpa mempertimbangkan kemungkinan kreatif. Solusinya terlihat jelas dan sederhana bagi kelompok, dan sedikit penggalian ide

b. Posisi awal diberikan oleh sebagian besar anggota tidak pernah mengkaji kembali untuk mencari hal yang tidak dapat diduga. Atau kelompok tidak kritis dalam menguji percabangan solusi.

c. Kelompok gagal menguji kembali semua alternatif yang bukan dari mayoritas. Pendapat minoritas akan dibiarkan atau tidak dianggap semua pihak

d. Pendapat para ahli tidak dicari dan kelompok puas dengan pendapat dan kemampuannya sendiri untuk membuat keputusan, dan mungkin merasa terancam dengan orang luar.

e. Kelompok sangat selektif dalam mengumpulkan dan menghadirkan informasi yang ada, dan hanya memusatkan pada informan yang mendukung rencana.

f. Kelompok begitu percaya diri dengan ide-idenya yang tidak mempertimbangkan kemungkinan kemungkinan dari rencana

Semua hal ini adalah hasil dari pemikiran yang kurang kritis dan dari kelompok yang terlalu percaya diri. Dari fenomena pemikiran kelompok tadi menimbulkan gejala-gejala yang memperngaruhi kelompok. Gejala pertama yakni solusi kebal (illusion of invulnerability), yang menciptakan udara optimisme yang tidak sepantasnya. Kedua, kelompok menciptakan usaha kolektif untuk merasionalkan serangkaian tindakan yang diputuskan, ini menciptakan usaha kolektif untuk merasionalkan serangkaian tindakan yang diputuskan, Nampak benar dan pembicaraannya memang memikirkan hal yang benar. Ketiga, kelompok menjaga sebuah kepercayaan yang tidak terpatahkan dalam moralitas bawaannya. Keempat, pemimpin diluar kelompok memiliki stereotipe. Kelima, tekanan langsung mendesak anggota untuk tidak mengungkapkan pendapat. Keenam sensor diri dari pertentangan. Ketujuh, ada sebuah ilusi mufakat (illusion of unanimity) dalam kelompok. Akhirnya pemikiran kelompok melibatkan kemunculan pikiran waspada (mindguards) yang diangkat sendiri untuk melindungi kelompok dan pemimpin dari 
opini berlawanan dan informasi yang tidak diinginkan.

Hal ini yang dicoba penulis untuk menerapkan teori ini pada kelompok pecinta ayam jago aduan yang memiliki anggota yang kohesif. Setiap anggota pada kelompok ini dituntut untuk menjaga kondisi internal kelompok supaya tidak terjadi kesenjangan. Terutama meminimaliskan adanya ketidakterbukaan dalam mengadu ayam jago aduan.

\section{HASIL PENELITIAN}

\subsection{Infroman 1}

Dalam komunitas ini ternyata juga ditemui beberapa masalah dan keunikan tersendiri, seperti dalam menyelesaikan sebuah masalah antar anggota kelompok ternyata akan dikucilkan, dan tidak dihakimi sesuai aturan dalam kelompok tersebut. Nantinya anggota yang dikucilkan ini akan merasa bersalah dan mundur dari kelompok ini, selain itu dalam komunitas ini jika salah satu individu mengalami kesulitan dalam melatih ayam jago aduannya, dapat menitipkan ayam tersebut di tempat peneliti melakukan penelitian untuk dilatih secara benar guna menjadi ayam jago yang kuat dalam bertarung, selama ini Handoko dikenal dalam kelompoknya sebagai orang yang dituakan dan mengerti bagaimana membuat ayam jago biasa menjadi ayam petarung yang hebat. Oleh karenya. Dari anggota kelompok ini banyak yang meminta tolong untuk di latih ayamnya, namun demikian hal tersebut ternyata dilakukan dengan gratis, sehingga dari sikap ini Handoko di tua kan dalam kelompok pecinta ayam jago aduan di manyaran ini.

Selain masalah yang ada dalam kelompok, masalah lain juga muncul dalam bentuk protes dari masyarakat sekitar di wilayah manyaran. Wilayah manyaran ini merupakan padat penduduk, selain itu tempat yang berada di perbukitan ini menjadikan kurangnya lahan bagi handoko yang juga menjadi peternak ayam jago untuk melepaskan ayamnya. Ayam - ayam miliknya sering masuk ke pekarangan rumah dan kebun tetangganya, sehingga konflik adu mulut antara tetangga ini pun sering terjadi karena merasa risih dengan ayam dan juga kotoran ayam yang ada dimana mana. Namun demikian meski protes dan adu mulut sering terjadi handoko tidak mempermasalahkan dan cenderung acuh tak acuh. Hal ini merupakan salah satu dampak negatif dengan adanya komunitas pecinta ayam jago ini terlebih jika para anggotanya berkumpul dan membawa ayam jagonya masing-masing maka, jalan kampung ini akan dipadati sepeda motor milik para anggota yang mengganggu aktivitas lainnya.

Ketika terjadi bentuk protes dari masyarakat yang tidak menyukai adanya ternak ayam dalam bentuk besar yang dinilai mengganggu kenyamanan warga lain, solusi yang dilakukan handoko sendiri yakni dengan meminimalisir ayam yang dia miliki untuk tidak menjamah ke rumah warga yang protes dengan keberadaan ayam-ayam ini. Hal ini yang dianggapnya cara ampuh untuk membuat nyaman warga yang tidak setuju dengan keberadaan mereka

\subsection{Informan 2}


Menurut Cipto salah satu warga yang tinggal di wilayah ini menyebutkan keberadaan kelompok ini dapat mengancam kenyamanan dan keamanan terhadap kampung ini. Kegiatan tersebut dinilainya sangat tidak baik untuk dilihat generasi anak - anak karena dapat mengajarkan secara tidak langsung judi sabung ayam di wilayah manyaran ini. Tidak hanya itu kegiatan ini jelas dilarang agama dan melanggar hukum.

“ jelas kan mas, judi ayam ini aja kalau pas totohan (taruhan) pindah-pindah dan tidak berani disini. Itu kan bukti kalau kegiatan ini dapat dipidanakan, coba kalau polisi sampai tahu dan menggropyok kampong kami, jelas warga yang tidak ikut-ikutan jadi kena getahnya"

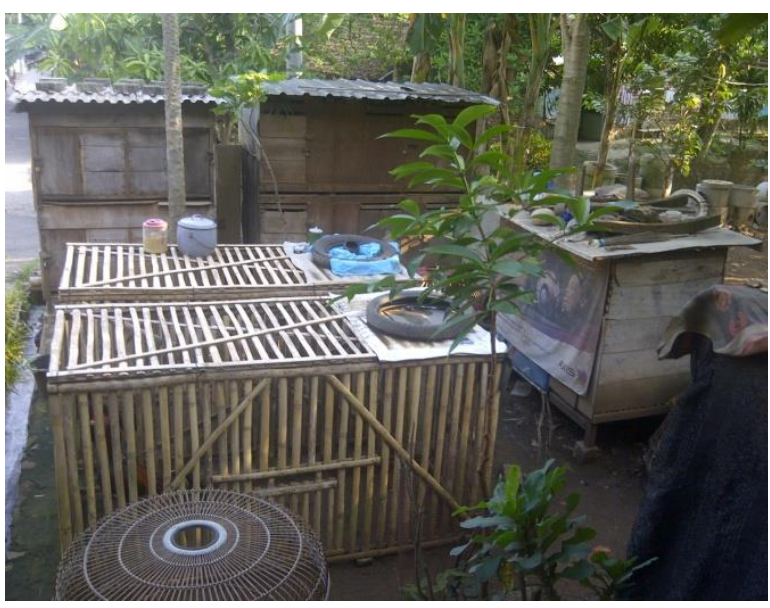

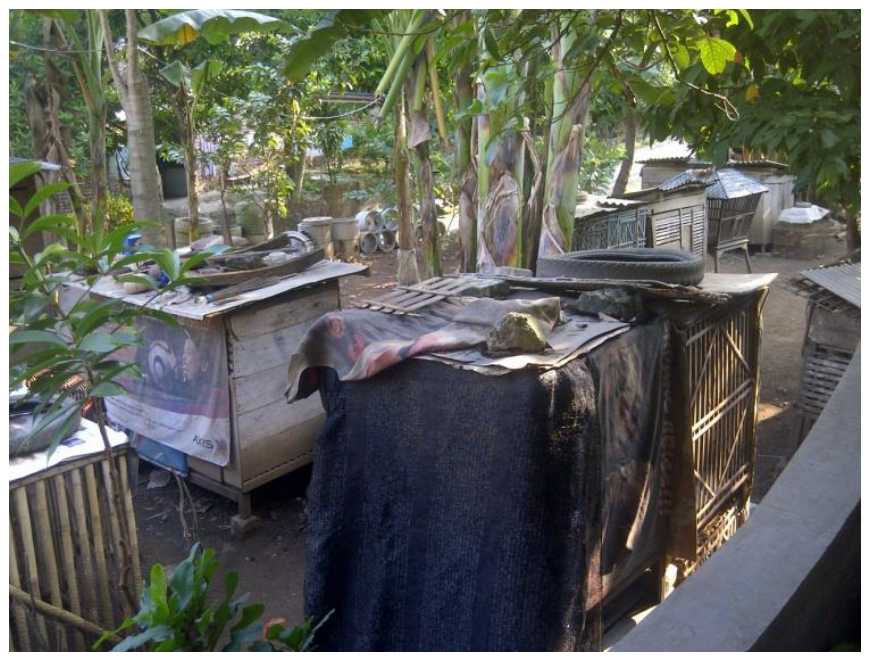

Dari gambar diatas terlihat bahwa kandang ayam yang dimiliki kelompok ini nampak kumuh, dan rentan akan penyakit. Hal ini yang menjadi penyebab sebagian warga yang tidak setuju atas keberadaan kelompok ini, namun hal itu tidak dihiraukan kelompok ini.

Nada kesal juga sering di ucapkannya terkait kotoran ayam yang ada dimana-mana lantaran ayam-ayam di biarkan berkeliaran diluar kandangnya. Selain itu adanya anggota kelompok dari daerah lain juga membuat kekawatiran tersendiri bagi Cipto. Menurutnya proses komunikasi dengan para anggota sabung ayam yang menjadi tetangganya sendiri menjadi renggang, interaksi pun dilakukan apabila ada keperluan yang menyangkut dengan kebutuhan warga kampung lainnya seperti kegiatan gotong royong kampung. Hal ini dikatakan cipto sebagai dampak sosial yang ia dapat ketika memprotes adanya kelompok ini, namun ia merasa tidak masalah jika dalam lingkup sosialnya ia di jauhi masyarakat atau warga mayaoritas yang menjadi anggota pecinta ayam jago ini.

Cipto sendiri mengaku untuk membuat ayam-ayam tersebut masuk ke 
pekarangan rumahnya, ia membuat pagar rumah yang ditembok setinggi 1 meter disertai dengan pecahan kaca. Menurutnya dengan cara mengalah itulah ia dapat merasa nyaman dari gangguan kelompok ini.

\subsection{Informan 3}

Dalam interaksinya kelompok ini memang tidak melakukan hal-hal aneh dalam lingkungan karena sabung ayam yang selama ini dilakukan menggunakan sistem korea atau berpindah-pindah guna tidak terendus pihak kepolisian, selama berkumpul di rumah handoko mereka sekedar main atau tidak ada hal-hal yang ingin diketahui, seperti membuat ayam jago yang dimiliki lebih kuat dan hebat lagi. Diluar itu menurut observasi penulis, kegiatan sparring atau latih tanding ayam aduan dilaksanakan hanya untuk melihat sejauh mana kemampuan ayam petarung yang sudah di latih, Hal ini dilakukan tanpa melibatkan uang atau taruhan.

Hal ini juga diamini oleh salah satu anggota dari kelompok pecinta ayam jago aduan Heru atau dalam kelompok ini dipanggil Kriting, meski hanya memiliki 4 ayam jago aduan dan sering berinteraksi dalam kelompok ini namun dirinya jarang sekali melakukan judi sabung ayam. Ini terhitung sejak 3 tahun mengenal ayam jago aduan, pihaknya mengaku hanya 10 kali melakukan judi sabung ayam. Pria yang bekerja sebagai pegawai kantoran ini pun mengaku tidak begitu suka dengan judi sabung ayam, terlebih sudah hidup cukup dengan bekerja.

“ mengenal sabung ayam dan memelihara ayam jago aduan ini saya lakukan sejak tahun 2011 lalu awalnya hanya iseng-iseng waktu kosong, kan sabtu minggu saya libur, jadi ya saya tertarik awalnya ikut-ikutan aja. Tapi lama-lama mulai dari satu ekor saya beli lagi dari kecil saya pelihara hingga sekarang memilki 4 ekor ayam. Sebenarnya kalu judi sabung ayam saya kurang begitu suka, namun kalau sparing-an saja saya mau, karena ingin melihat sejauh mana kekuatan ayam jago saya, dan melihat perkembangannya."

Meski begitu Heru dan anggota lain saling menghormati dan tidak ada sangsi untuknya karena tidak melakukan judi sabung ayam saat anggota ini melakukannya. Hal yang sama juga ditunjukan heru dengan menghormati anggota lain yang melakukan judi sabung ayam, salah satunya untuk tidak pernah menasehati perihal kegiatan yang melanggar UU terkait perjudian. Sikap saling menghormati inilah yang membuat antar anggota menjalin hubungan yang kuat dan tercipta rasa saling menjaga antar anggota kelompok.

Sabung ayam memang tidak bisa jauh dari judi, karena dalam hal ini, pertarungan para ayam di pertaruhkan dengan uang tidak heran jika kegiatan ini dilakukan terselubung selain itu jika generasi anak-anak sudah mengetahui dan ikut berpartisipasi dalam kegiatan ini, dikhawatirkan akan ada penerus negatif dari aktivitas tersebut. Namun sulit memang karena sabung ayam merupakan sebuah tradisi turun temurun bahkan juga tertuang dalam sebuah lagu anak - anak, hingga dongeng. Bahkan pihak kepolisian dirasa kewalahan membrantas aktivitas judi sabung ayam.

Untuk mensiasati agar tidak tercium dengan pihak berwajib, kelompok ini melakukan judi sabung ayam dengan cara berpindah-pindah atau sistem Korea. 
Sistem tersebut sudah terbukti lama berhasil mengelabui pihak kepolisian, selama mereka melakukan judi sabung ayam, kelompok ini tidak pernah terkena operasi polisi.

Jika dilihat kelompok pecinta ayam jago aduan ini merupakan sebuah kelompok yang memiliki cara pandang sendiri terhadap para anggotanya. Dalam kelompok ini tidak ada yang menjadi ketua sebagaimana kelompok-kelompok lainnya. Namun hanya saja orang yang di segani dan dianggap paling mengerti tentang ayam jago yang paling besar mendapat respect atau dihormati anggota lain. Seperti yang dijabarkan dalam bukunya (Littlejohn, 2009: 346) groupthink theory karya Irving Janis dan koleganya menyebutkan pemikiran kelompok sebagai sebuah hasil langsung terhadap kepaduan kelompok. Kepaduan adalah tingkat minat ganda diantara anggota kelompok, sedangkan dalam kepaduan adalah sebuah hasil dari tingkatan yang sama semua anggota merasa memiliki tujuan yang sama dan ingi di capai dalam golongan atau kelompok.

Kepaduan adalah sebuah hasil dari tingkatan yang semua anggita merasa bahwa tujuan mereka dapat tercapai dalam golongan. Hal ini tidak membutuhkan anggota yang memiliki sikap yang sama namun anggota yang menunjukan sebuah tingkatan saling ketergantungan, bersandar pada satu sama lain untuk meraih tujuan yang diingini. Dengan demikian semaikin kelompok padu, tekanan akan lebih mendesak anggota untuk menjada kepaduan.
Dalam penelitian Janis (Littejohn, 2009:346) menemukan pemikiran kelompok dapat menghasilkan sesuatu yang negatif :

4.2.1 kelompok membatasi diskusi hanya untuk beberapa alternatif tanpa mempertimbangkan kemungkinan kreatif. jika di kaitkan dengan penelitian terkait kelompok pecinta sabung ayam di wilayah manyaran terlihat pada diskusi yang dilaksanakan terkait dengan persoalan yang dihadapi dengan warga yang menolak keberadaan kelompok tersebut, selain itu dalam diskusi soal membentuk ayam jago yang kuat dalam bertanding atau diadu, hanya orang yang dituakan dalam kelompok ini yang dipercaya, sedangkan anggota lain yang memiliki cara tersendiri dalam melatih selalu diremehkan meski ayam jago yang dimiliki juga mampu bertarung dengan kuat.

4.2.2 posisi awal diberikan oleh sebagian besar anggota tidak pernah dikaji kembali untuk mencari hal yang tidak dapat diduga, dengan kata lain kelompok tidak kritis dalam menguji percabangan lain.

4.2.3. Kelompok gagal untuk menguji kembali semua alternatif yang bukan dari mayoritas. Pendapat minoritas dengan cepat dibubarkan dan diabaikan, tidak hanya oleh mayoritas, namun semua yang awalnya sepihak. Disimpulkan bahwa suara mayoritas dalam kelompok ini merupakan suara yang mutlak dan di sepakati bersama dengan demikian setiap anggota menghormati keputusan mayoritas. Dicontohkan dalam pandangan judi sabung ayam, para anggota lebih banyak yang suka melakukannya.

4.2.4. Pendapat para ahli tidak dicari, kelompok puas dengan pendapat dan 
kemampuannya sendiri untuk membuat keputusan dan mungkin merasa terancam dengan keberadaan orang luar. Seperti yang terlihat dalam kelompok sabung ayam di manyaran ini, jika dikaitkan dengan respon kelompok ini terhadap kritikan atas keberadaan ayam milik para anggota dirasa menjadi ancaman bagi kelompok ini. Sehingga sikap menjauhi warga minoritas dengan mengucilkan mereka dirasa hal yang pantas untuk menghukum keberadaan mayoritas warga yang menjadi kelompok pecinta ayam jago ini. Selain itu terkait dengan kotoran ayam yang dibiarkan dengan jumlah yang banyak akan menimbulkan kuman-kuman atau sarang penyakit yang mengancam kesehatan warga lain. Terutama anak kecil yang sering bermain di dekat peternakan ayam ini, tak hanya itu polusi bau yang ditimbulkan juga mengganggu warga. Namun demikian kelompok ini menilai hal yang wajar dan tidak menjadi masalah yang besar. Sikap inilah yang menjadikan kelompok ini dipandang negatif sebagian warga.

4.2.5. Kelompok sangat selektif dalam mengumpulkan dan menghadirkan informasi yang ada. Anggota cenderung memusatkan hanya pada informasi yang mendukung rencana kelompok. Sesuai dengan pandangan atau sikap kelompok pecinta ayam jago ini, semua yang dianggap setuju atau tidak bermasalah dengan keberadaan kelompok ini, maka mereka masih menganggapnya sebagai tetangga yang baik, namun apabila menentang maka akan dijauhi atau dikucilkan anggota kelompok ini yang menjadi warga mayoritas.

4.2.6. kelompok begitu percaya dengan ide-idenya yang tidak mempertimbangkan kemungkinan kemungkinan dari rencana.
Dari penemuan ini Janis menilai hasilnya kurang kritis dan dari kelompok terlalu percaya diri.

Gejala pertama yakni solusi kebal (illusion of invulnerability), yang menciptakan udara optimisme yang tidak sepantasnya. Kedua, kelompok menciptakan usaha kolektif untuk merasionalkan serangkaian tindakan yang diputuskan, ini menciptakan usaha kolektif untuk merasionalkan serangkaian tindakan yang diputuskan, Nampak benar dan pembicaraannya memang memikirkan hal yang benar. Ketiga, kelompok menjaga sebuah kepercayaan yang tidak terpatahkan dalam moralitas bawaannya. Keempat, pemimpin diluar kelompok memiliki stereotipe. Kelima, tekanan langsung mendesak anggota untuk tidak mengungkapkan pendapat. Keenam sensor diri dari pertentangan. Ketujuh, ada sebuah ilusi mufakat (illusion of unanimity) dalam kelompok. Akhirnya pemikiran kelompok melibatkan kemunculan pikiran waspada (mindguards) yang diangkat sendiri untuk melindungi kelompok dan pemimpin dari opini berlawanan dan informasi yang tidak diinginkan.

Dalam kelompok ini setiap anggotanya dituntut untuk menjaga kelompoknya supaya tidak terjadi kesenjangan, seperti yang diungkapkan Heru salah satu anggota kelompok pecinta ayam jago aduan di wilayah manyaran ini. Pihaknya bersama dengan anggota lain selalu menjaga komunkasi dengan baik, berupaya bersikap baik dan tidak saling menjatuhkan ketika berinteraksi dalam kelompok ini. Dalam kasusnya dilapangan kelompok ini masukan dari warga lain yang menginginkan kegiatan dalam kelompok pecinta ayam jago aduan 
ini dibubarkan telah disampaikan dalam sebuah forum atau pertemuan warga namun tetap saja karena suara minoritas warga yang sedikit menyebabkan tidak mempengaruhi aktifitas atau keberadaan kelompok ini yang merupakan mayoritas warga setempat.

Setiap anggota dalam kelompok ini memang memiliki kesibukan masingmasing diluar kecintaannya memelihara ayam jago, oleh karenanya setiap berkumpul melakukan interaksi kelompok ini anggotanya tidak semuanya dapat hadir secara rutin. Namun demikia interaksi mereka tetap berlangsung baik bahkan jika salah satu dari anggota ini tidak pernah berinteraksi maka anggota lain akan mencari tahu bahkan hingga mendatangi rumahnya. Sikap seperti ini yang membuat komunitas ini tetap solid dan ada hingga saat ini. Sehingga dari sini sikap menghormati antar anggota juga tetap dijaga.

Dalam komunikasi kelompok memandang sebuah proses sebagai instrument disaat kelompok membuat keputusan, menekan hubungan antar kualitas komunikasi dan hasil dari kelompok (Littlejohn, 2009: 344). Hal ini dapat Penulis gunakan untuk mencari tahu kerusakan dalam pemikiran mereka dan sebuah cara persuasi. Digambarkan kelompok ini memandang sebuah kontra sebagai salah satu dinamika masyarakat yang hanya ditanggapi masa bodoh dalam kelompok ini. Hal itu terlihat ketika kelompok ini menyikapi adanya protes dari warga yang tidak setuju dengan adanya kelompok ini yang dianggap akan membuat jelek nama kampung mereka. Ada anggapan suara mayoritas mengalahkan suara minoritas, dalam kenyataannya dikampung ini memang banyak sekali warga yang menjadi anggota pecinta ayam jago aduan sehingga segelintir warga ini hanya dianggap angin lalu bagi kelompok ini. Terlebih mulai dari pemuka agama hingga orang yang dituakan dalam kampung ini pun juga ikut menjadi anggota dalam kelompok ini.

Jika dilihat observasi Penulis selama melakukan penelitian, kelompok ini memang tidak peduli dengan kritikan masyarakat sekitar yang tidak setuju dengan keberadaan mereka. Setiap anggota dalam kelompok pecinta ayam jago aduan ini menilai bahwa kegiatan sabung ayam jago ataupun memelihara ayam jago dalam jumlah yang banyak merupakan hal yang wajar, mereka tidak melihat lingkungan dan kemampuan dalam memelihara ayam dengan jumlah yang mencapai puluhan, warga yang tidak setuju menilai limbah kotoran ayam dari kandang peternak ini, tidak pernah dipikirkan pemiliknya. Hal ini seperti dalam buku (Littlejohn, 2009: 33) dalam teori Pengambilan keputusan ini Fisher mengutip empat fase melalui kelompok yang cenderung mengolah : orientasi, konflik, kemunculan dan penguatan. Toeri Fisher ini membuat sadar pentingnya sebuah interaksi sebagai proses dasar komunikasi yang mengubah input menjadi output (Littlejohn, 2009: 335). Dalam prilakukanya, fenomena pemikiran kelompokyang dijelaskan dalam karya Irving Janis dan koleganya dalam buku (Littlejohn, 2009: 347) Gejala pertama adalah solusi kebal (illusion of invulnerability), yang menciptakan sebuah udara optimisme yang tidak sepantasnya, yakni ada rasa yang sangat kuat yang di ungkapkan dengan "kita tahu apa yang kita lakukan, jadi jangan goyang perahu kami". 
Selain itu dalam kelompok ini istilahistilah yang digunakan untuk mengelabuhi petugas keamanan sering dilakukan, seperti istilah korea yang berarti berpindah-pindah melaksanakan judi sabung ayam. Sejauh ini melalui sistem korea mereka tidak pernah terendus pihak kepolisian dan kegiatan sabung ayam masih terlaksana hingga sekarang.

Jika dilihat dalam analisis Fisher dalam buku (littlejhon, 2009: 333) mengacu pada tindakan individu, B. Aubrey Fisher dan Leonard Hawes dengan acuan pendekatannya sebagai sebuah model sistem manusia (system human model), yang tidak fokus pada tindakan tetapi pada "interaksi." Sebuah interaksi adalah tindakan dari seseorang yang di ikuti dengan tindakan yang lainnya - sebagai contoh, tanya jawab, pernyataan pernyataan dan sapa-menyapa. Disini, unit analisis tidak pada pesan sesorang, seoerti memberi saran tetapi bagian dari tindakan yang berkesinambungan seperti memberi saran dan meresponsnya.

Dalam kenyataan dilapangan interaksi dilakukan setiap anggota dengan baik, bahkan jika ada salah satu anggota dari kelompok ini yang memiliki permasalahan terkait dengan ayam jago aduannya ataupun hal lain akan dibantu menyelesaikannya. Seperti yang sering dilakukan Handoko yang sering membantu anggota lain untuk menjadikan ayam jago aduan ini semakin baik dalam bertarung.

\section{Kesimpulan}

Keberadaan pecinta ayam jago aduan ini menimbulkan pro dan kontra dari warga lain, mereka kurang setuju dengan aktivitas kelompok ini, namun demikian banyak warga yang tidak memperdulikan protes tersebut karena berasal dari suara minoritas warga sehingga justru warga tersebut dikucilkan masyarakat yang mayoritas anggota kelompok pecinta ayam jago aduan ini. Salah satu temuan dalam penelitian yang menarik yakni Proses menghadapi kritik dari luar yang dilakukan kelompok ini cukup ektrim dengan tidak menggangap warga yang menolak keberadaan kelompok ini, karena menganggap suara minoritas, seperti yang dicontohkan dalam buku (Littlejohn, 2009: 346) terkait dengan pemikiran-pemikiran negative dari kelompok ini.

Selain itu meski keberadaan mereka berpotensi merusak nama baik kampung ini, para anggota kelompok tidak pernah melakukan sabung ayam di wilayah ini dan memilih untuk berpindah - pindah melakukan sabung ayam. Interaksi para anggota pun juga tidak dilaksanakan setiap hari, karena setiap anggota kelompok pecinta ayam jago aduan ini memiliki kegiatan masing-masing, namun lebih pada hari libur kerja seperti hari minggu.

Selain itu dalam kelompok Pecinta ayam sabung ini para anggotanya mulai dari tokoh di kampung manyaran, pemuka agama, hingga remaja. Dapat disimpulkan bahwa untuk menjadi anggota kelompok ini tidak memandang usia asalkan samasama memiliki kegemaran dan memelihara ayam jago aduan (Bangkok) untuk masuk menjadi anggota pun tidaklah sulit, berbeda dengan kelompok lain yang biasanya mewajibkan melalui tes, aturan-aturan tertentu hingga prosesi turun temurun sesuai dengan kebiasaan kelompok. Hal ini yang menyebabkan semakin banyaknya anggota pecinta ayam 
aduan di wilayah manyaran ini bahkan hingga warga dari luar manyaran.

Temuan lain dalam penelitian ini yakni cara mereka mengelabui petugas kepolisian dengan menggunakan sitem korea dimana kelompok ini melakukan judi sabung ayam atau taruhan untuk ayam jagoannya dengan cara berpindahpindah tempat. Tidak hanya itu, adanya oknum yang memback-up kegiatan judi sabung ayam ini membuat kelompok ini tetap mempertahankan kesenangannya dengan mengadu ayam jago yang dipelihara dan dirawat untuk bertarung. Selain alas an uang juga unsur kecintaan akan binatang berjenis unggas ini menyebabkan kelompok tetap utuh dan memiliki kesenangan yang sama sehingga jika merasa ada yang mengancam keberadaan atau keutuhan kelompok pecinta ayam jago aduan ini maka, pihak tersebut akan dimusuhi bersama.

\section{Saran}

Subyek penelitian ini dapat dilanjutkan atau dikembangkan peneliti lain dengan menggunakan metodologi dan aspekaspek lainnya, jika dalam penelitian ini Peneliti menggunakan metodologi deskriptif kualitatif maka untuk peneliti lain dapat menggunakan metode lain seperti metode Fenomenologi. Metode Fenomenologi menurut Polkinghorne (Creswell, 1998: 51-52) yang menggambarkan arti sebuah pengalaman hidup untuk beberapa orang tentang sebuah konsep atau fenomena. Orangorang yang terlibat dalam menangani sebuah fenomena melakukan eksplorasi terhadap struktur kesadaran pengalaman hidup manusia. Sedangkan menurut Husserl (Creswell, 1998: 52) Peneliti fenomenologis berusaha mencari tentang, hal-hal yang perlu (esensial), struktur invarian (esensi) atau arti pengalaman yang mendasar dan menekankan pada intensitas kesadaran dimana pengalaman terdiri hal-hal yang tampak dari luar dan hal-hal yang berada dalam kesadaran masing-masing berdasarkan memori, image dan arti.

\section{DAFTAR PUSTAKA}

Abu Ahmadi. 2002. Psikologis Sosial. Jakarta: Rineka Cipta.

Anwar Arifin. 1984. Strategi Komunikasi: Suatu Pengantar Ringkas. Bandung: Armico.

Collins, Barry dan Harold, Guetzkow. 1964. A Social Psychology off Group Processes for DecisionMaking. New York: Wiley.

Curtis, B., Floyd, James J., Winsor, Jerry L. 2005. Komunikasi Bisnis dan Profesional. Bandung: PT Remaja Rosdakarya.

Deddy Mulyana. 2005. Ilmu Komunikasi: Suatu Pengantar. Bandung: PT Remaja Rosdakarya.

Littlejohn, Stephen. 2009. Teori Komunikasi (Edisi terjemahaan oleh Karen A, Foss). Jakarta: Salemba Humanika.

Masri Singarimbun. 1989. Metode Penelitian Survey. Edisi Revisi. Jakarta: LP3ES.

Moch. Nazir. 2003. Metode Penelitian. Jakarta: Salemba Empat.

Noeng Muhajir. 1996. Metode

Penelitaian Kualitatif. Yogyakarta: Rake Rasasin.

Suharsimi Arikunto. 2006. Prosedur penelitian Suatu Pendekatan praktek. Jakarta: Rineka Cipta 
Sugiyono. 2007. Metode Penelitian kuantitatif, kualitatif dan $r \& d$. Bandung: Alfabeta

Wiryanto. 2005. Pengantar Ilmu Komunikasi. Jakarta: Gramedia Widiasarana Indonesia.

http://adiprakosa.blogspot.com/2008/07/k omunikasi-kelompok.html; Adioprakosa; komunikasi kelompok; diunduh pada tanggal 18 Mei 2014 pukul 19:37.

http://www.ternakayamkampung.com; diunduh pada 18 Juni 2014 20:09

http://embakri.wordpress.com/2009/03/12 /fenomenologi; diunduh pada 19 Juni 2014 pukul 14:30 Wib 